\title{
Structural Configurations of Social Representations about Climate Change
}

\author{
By Marshaley J. Baquiano* \\ Ana Joy P. Mendez ${ }^{\dagger}$
}

\begin{abstract}
The study looked at college students' meaning-making of climate change, using the lens of Social Representation Theory. Participants were 130 undergraduate students of the University of Guam who were asked to answer a free association questionnaire in which they were to write the first three ideas that came to mind regarding their understanding and description of climate change, Abric's (2012) Hierarchical Evocation Method (HEM) was used in analyzing the data. Central to the understanding of students is that climate change is synonymous with global warming. Peripheral apprehension of climate change include seeing climate change as modifications in weather, temperature, and season; associating the social object with calamities and disasters, environmental destructions, as well as the effects of these changes on human beings and animals; and the adjustments that human beings have to take on as a form of adaptation. Climate change is also socially understood as weather that has become extreme and unpredictable. Results have implications on the development and implementation of policies on climate change mitigation and adaptation.
\end{abstract}

Keywords: Climate Change, Guam, Hierarchical Evocation, Social Representation Theory

Climate Change is the long-term change of weather patterns, either due to natural variability or as a result of human activity (IPCC 2007, Haywood and Schulz 2007). It is an issue discussed by various sectors of society all over the world because its effect would affect all inhabitants of this planet.

Different countries have responded to the issues in various ways. In the Philippines, Republic Act 9729, also known as the Climate Change Act of 2009 was enacted to ensure protection, not just of the environment, but of the people as well. The law promotes sustainable development so as to meet human needs while at the same time safeguarding the environment for the current and future generations.

As climate change is believed to be mostly caused by human activities (Claussen 2001), many studies have been conducted to investigate the phenomenon more closely. Some of these studies looked at how human beings have contributed to climate change, and some at how people have reacted to it. There are also studies that examined what measures have human beings done to mitigate climate change as well as how they have adapted to. Most of these studies obtained the points of view of experts in the field.

*Assistant Professor, University of the Philippines Visayas, Philippines.

${ }^{\dagger}$ Division Chairperson/Assistant Professor, University of Guam, USA. 
Not many studies, however, were conducted that looked into how climate change is understood by the "ordinary people". The term, ordinary people, here refers to those who are not experts of climate change. These are people who may "experience" climate change, but who are not scientifically/academically studying the phenomenon.

The theory of social representation was used in the conduct of this study. The theory looks at people's everyday talk about a particular social object (Moscovici 1988). Social representation is defined by Wagner et al. (1999) as the "ensemble of thoughts and feelings being expressed in verbal and overt behavior of actors which constitutes an object for a social group. It is a collective phenomenon that pertains to a community and co-constructed by individuals in their everyday talk and action. These representations reside across the minds of these co-acting individuals" (Wagner et al. 1999: 96).

Jodelet (2006) described a structural approach to explain representations which consists of central and peripheral elements. The central core is the main element, determining the significance of the representation as whole (its generating function), as well as its structure (its organizing function). It is stable and non-negotiable. The central system plays a key role in the functioning and the dynamics of representations (Abric 1996). The peripheral elements, on the other hand, give concrete content and expression to the central system as well as perform the functions of regulation, adaptation, and protection of the central system (Abric 2012).

Various studies about climate change have already been conducted by different researchers belonging to different fields - natural sciences, social sciences, and agriculture, amongst others. The central points of these research studies vary, according to the field of specialization of the researchers as well as the angle at which they show preference for. For instance, Jose and Cruz (1999), as well as Kelkar and Bhadwal (2007) investigated the impacts of climate change on the environment in general and Hughes (2003) looked at the impact of climate change in Australia in particular. Cotton (2003) focused on the effect of climate change specifically on biodiversity. The four studies emphasized the vulnerability of our resources to climate change.

Social scientists, on the other hand, focus on the impacts of the phenomenon on people and their lives. For instance, Hunter (2003) studied diseases brought about by climate change; Patz, Campbell-Lendrum, Holloway, and Folley (2005) looked at the impacts of climate change on human health; and O'Brien and Leichenko (2000) investigated the combined impact of climate change and economic globalization on people's lives.

Other scientists looked at how the world adapts to climate change. For instance, Berang-Ford et al. (2011), believing that human systems have to adapt to climate change, studied how this adaptation is taking place. Wanting to be more specific, Berkes and Jolly (2001) examined the social-ecological resilience of a Canadian western arctic community as the people tried to adapt to climate change. Tompkins and Adger (2004), on the other hand, looked at the value of building resilience in both human and ecological systems in coping with changes in the environment. 
There are also those that examine possible ways of mitigating the impacts of climate change. For instance, Betsill (2001) studied the probable opportunities and obstacles that may be encountered in trying to mitigate the brunt of climate change in the United States of America.

Looking at these studies, it can be seen that studies on climate change focus on the impacts of the phenomenon, on how people adapt to it, and what can be done to mitigate the impacts of climate change. Very few studies, however, look into people's shared understanding of the phenomenon; or look into the experts' meanings vis-à-vis lay apprehension of climate change. Knowing people's understanding of climate change is as important as knowing its impacts or how to tone down its effects.

This study aimed to capture the social representations of climate change. Specifically, this study intended to answer the following questions:

1. How is climate change socially represented by the youth and young adults of Guam?

2. What are the structures of their social representation?

a. What is the central core?

b. What are the peripheral elements?

\section{Methods}

The study aimed to capture the social meanings that students of the University of Guam make of climate change. In doing so, the Hierarchical Evocation Method advocated by Abric (2012) was used.

Participants were 130 undergraduate students of the university. Sixty eight percent $(68 \%)$ were females, $26 \%$ were males, and the remaining $6 \%$ did not indicate gender. These students ranged between 17 and 45 years old $(M=23.5$, $S D=5.17)$. Using the free association technique, respondents were asked to answer the question, what comes to your mind when you think of climate change? The participants wrote the first ideas that came to their minds upon reading the question. They were made to write as many as 3 answers.

Adhering to the steps advanced by Abric (2012) in doing hierarchical evocation method, answers in the free word association technique were first reduced using thematic analysis so that the answers were trimmed down and eight themes or categories remained.

Following the examples conducted in other studies using hierarchical evocation method (see Gomes et al. 2008, Roland-Levy et al. 2010, and Walchelke 2008) the rate of the responses' frequency and average ranking of importance were crossed so as to obtain the structure of the respondents' social representations. The average frequency was computed by dividing the number of occurrences of words included in the analysis by the number of categories. As 3 answers were solicited from the respondents, we also assigned 2 as average evocation order.

The analysis was plotted using a four-area chart. The upper left corner contained the core elements, the upper right corner the elements of the first 
periphery, the lower left corner the contrasting elements, and the lower right corner the second periphery. Themes or categories that were mentioned more repeatedly and more promptly (i.e. first mentioned) were placed on the quadrant of the central core. Those that were mentioned more repeatedly but less promptly were placed in the quadrant of first periphery. Elements that were more promptly but less repeatedly mentioned were placed in the quadrant of contrasted elements and those that were mentioned less frequently and less promptly were placed in the quadrant of second periphery.

\section{Results}

Analysis of the evocation corpus that focuses on the understanding of climate change revealed 362 words/expressions/statements, which, when analyzed using thematic analysis were reduced to 8 themes. Words/expressions/statements belonging categories that had very low frequency (5\% or less of the total frequency) were excluded from the analysis. Table 1 presents the frequency of occurrence and examples of words included in each category as expressed by the students.

Table 1. Category, Sample words, and Frequency of Occurrence Generated from Free Evocation Task about Climate Change

\begin{tabular}{|c|c|c|c|}
\hline & Category & Sample Words & Frequency \\
\hline 1 & Global warming & $\begin{array}{l}\text { Global warming, greenhouse effects, global "wierding", } \\
\text { hot weather, hot gets hotter }\end{array}$ & 94 \\
\hline 2 & $\begin{array}{l}\text { Calamities, } \\
\text { disasters }\end{array}$ & $\begin{array}{l}\text { Typhoon, storms, floods, hurricanes, tsunami, water } \\
\text { surges, tornado, droughts, acid rain, earthquakes }\end{array}$ & 37 \\
\hline 3 & $\begin{array}{l}\text { Modifications in } \\
\text { weather, } \\
\text { temperature, } \\
\text { season }\end{array}$ & $\begin{array}{l}\text { Change in weather and temperature, seasonal change, } \\
\text { temperature changes, change in weather, change in } \\
\text { environment, ecological change, drastic temperature } \\
\text { change }\end{array}$ & 29 \\
\hline 4 & $\begin{array}{l}\text { Environmental } \\
\text { destruction }\end{array}$ & $\begin{array}{l}\text { Thinning of ozone layer, lacks water resources, disturbed } \\
\text { ecosystem, destruction of coral reefs, dying trees }\end{array}$ & 49 \\
\hline 5 & $\begin{array}{l}\text { Effects on } \\
\text { humans and } \\
\text { animals }\end{array}$ & $\begin{array}{l}\text { Loss of lives, people dying, people suffering, stress, } \\
\text { illness, diseases } \\
\text { Endangered species, animal migration, animals at risk, polar } \\
\text { bears (homeless), change in food cycle among animals }\end{array}$ & 29 \\
\hline 6 & $\begin{array}{l}\text { Extreme, } \\
\text { unpredictable, } \\
\text { bipolar weather }\end{array}$ & $\begin{array}{l}\text { Extreme hotness or coldness, on Guam it's hot/cold; } \\
\text { rain/shine, bipolar weather, unpredictable weather, seasons } \\
\text { unpredictable, temperature extremes, sunny t rainy }\end{array}$ & 22 \\
\hline 7 & $\begin{array}{l}\text { Cause of climate } \\
\text { change }\end{array}$ & $\begin{array}{l}\text { Pollution, carbon dioxide emission, overconsumption, } \\
\text { growing population, cutting of tress, industrialization }\end{array}$ & 22 \\
\hline 8 & $\begin{array}{l}\text { Human } \\
\text { adaptation }\end{array}$ & $\begin{array}{l}\text { Adjustment, great adjustment, adaptation, change of attire, } \\
\text { great change, acclimate, coping to different temperature }\end{array}$ & 19 \\
\hline \multicolumn{2}{|c|}{ Total Frequency } & & 301 \\
\hline \multicolumn{2}{|c|}{ Average Frequency } & & 38 \\
\hline
\end{tabular}

Table 2 shows the structure of the representation of the students of climate change. Central to the students' understanding of climate change is that it is almost synonymous with global warming. They see the environment as getting 
hotter, with the temperature getting higher. Along with this are the melting of the icebergs, the glaciers, and the polar caps in the Antarctic, and the rising of the sea level as a consequence and even disappearance of island nations.

Contrasted elements include associating climate change with disasters and calamities that are happening these days and seeing climate change as modifications in the patterns of weather, season, temperature, ecology, and some parts of the environment. The changes can be dramatic and drastic; or it can simply be gradual. Disasters and calamities, for them, include typhoon, storm, tornado, flood, hurricane, tsunami, earthquake, and water surge. Calamities may also come in the form of acid rain and drought.

Elements in the first periphery point to environmental destructions that result from the onset of climate change. This environmental destruction may take the form of devastated ecosystem, damaged coral reefs, dying trees, depleted ozone layer, and even diminishing water resources. The earth, according to them, is dying. This element is something that may not be mentioned promptly; however, they are mentioned frequently.

Elements in the second periphery, on the other hand, include what the respondents believe as the effects of climate change to animals and human beings, the causes of climate change, as well as the adaptive behaviors human beings have to get inured or desensitized to in response to changes in the environment. This quadrant also includes understanding climate change as weather that has become extremely hot and cold as well as unpredictable.

Climate change, according to the respondents, would endanger the lives of the animals. It could change the food cycle of animals, cause them to migrate, and even render the polar bears homeless. Human beings, on the other hand, may be caused much stress by the changing climate, as well as grapple with various forms of illness and diseases, which could lead to much suffering and even loss of lives. Causes of climate change for them include pollution and overconsumption caused by growing populations, industrialization, excessive cutting of trees, and high level of carbon dioxide emissions.

For many respondents, the changes in climate would cause human beings to adapt in order to cope and survive. Part of this adaptation would be to get acclimatized to changing temperatures as well as getting new sets of clothes that are weather-appropriate. This would entail much expense, especially in trying to convince people to act in relation to doing environmental conservation.

Lastly, respondents see the changes in climate as extreme as well as unpredictable. That is, climate change is associated with weather that could range from extremely hot and extremely cold. And this could happen anytime. The word commonly used by respondents is bipolar. Paralleled to mental disorder, the weather could swing from one extreme to another, unpredictably so. 
Table 2. Structure of the Representation of Climate Change among University of Guam Students

\begin{tabular}{|c|c|c|c|}
\hline & & \multicolumn{2}{|c|}{ AEO } \\
\hline & & Low Rank $(<2)$ & High Rank (> 2) \\
\hline & $\begin{array}{l}\text { High } \\
\text { frequency } \\
(>38)\end{array}$ & $\begin{array}{l}\text { ZONE OF CENTRAL CORE } \\
\text { Global warming }(f=94, A E O=1.63)\end{array}$ & $\begin{array}{c}\text { FIRST PERIPHERY } \\
\text { Environmental Destruction }(f=49, \\
A E O=2.10)\end{array}$ \\
\hline 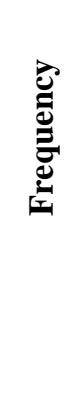 & $\begin{array}{l}\text { Low } \\
\text { frequency } \\
(<38)\end{array}$ & $\begin{array}{l}\text { CONTRASTED ELEMENTS } \\
\text { Calamities, disasters }(f=37 \text {, } \\
A E O=1.97) \\
\text { Modifications in weather, } \\
\text { temperature, season }(f=29 \text {, } \\
A E O=1.86)\end{array}$ & $\begin{array}{l}\quad \text { SECOND PERIPHERY } \\
\text { Effects on humans and animals } \\
(f=29, A E O=2.07) \\
\text { Extreme, unpredictable, bipolar } \\
\text { weather }(f=22, A E O=2.05) \\
\text { Causes of climate change }(f=22, \\
A E O=2.32) \\
\text { Human adaptation }(f=19, \\
A E O=2.11)\end{array}$ \\
\hline
\end{tabular}

\section{Discussion}

The study provides ideas how climate change is socially viewed from the perspective of the Guam youth and young adults, giving a glimpse of what goes on inside their minds. Understanding how this particular group perceives the phenomenon provides plausible cues as to the potential intervention that would most effectually work out where this group in the society is concerned. For instance, it can be noted that Guam youth and young adults find it vital for human beings to adapt to changing climate as way of survival. This adaptation may be physiological (e.g. getting acclimatized) or behavioral (e.g. getting weather-appropriate clothes). This indicates that for this particular group, preparation does matter. This is part of their social representation of climate change. This also gives a glimpse of the kind of policy and intervention that can best be crafted and implemented in terms of where climate change mitigation and adaptation are concerned. One example of an intervention would be introduction of carbon tax or tax levied on carbon context of fuels, which is conceivably cost-effective means of trimming down greenhouse gas emissions.

We wanted to reinforce the potency of social representation theory particularly in addressing social issues such as climate change. As we can see, findings of the study show the ideas of the youth and young adults in Guam which are formed and transformed through their interactions with one another (Moscovici 1988, Wagner et al. 1999), coupled with the influence of the media (Bauer and Gaskell 1999) and their culture (Levin-Rozalis 2001, Moscovici 2001). For instance, there is this perception that changes in climate are caused by pollution, carbon dioxide emission, overconsumption, and growing population, which could result to environmental destruction as well as suffering of both humans and animals. The respondents are clearly talking about a similar experience as well as experiences of other people in other parts of the world, as seen on television, read in the newspapers, or encountered on 
the internet. Social representation theory believes that recurrent social interactions serve as a background in which understanding of a social object is developed. And the explanations used to understand a social object are attached to various factors that link to the culture of the group.

This study collected and analyzed data to see how climate change is understood by the young adults. Another study that would explore how the problems related to climate change can be tackled as the people see it may enhance whatever data have already been collected here. It may also be interesting to look into how changes in climate are apprehended by specific groups, such as those who plant crops and catch fish, whose means of living is very much affected by changes in weather patterns.

\section{Conclusion}

Findings of the study point to two things: (1) social psychological research studies using a social representations approach can help surface group knowledge that could be integral in addressing social issues vexing our societies today; and (2) knowing how a group perceives, understands, and makes meaning of a social issue that is as crucial as climate change will give clear directions to policy makers and implementers how best to hew policies and how best to carry out interventions with due consideration to a group's cultural background.

These two points reinforce the value of Social Representation Theory as an analytical framework in investigating social phenomena that beset current societies. They highlight the usefulness of the theory in exploring various issues that vitally need to be understood and addressed.

\section{References}

Abric J (2012) A structural approach to social representations: The central coretheory. In R. Permanadeli, D. Jodelet, \& T. Sugiman (Eds.) Alternative Production of Knowledge and Social Representations: Proceedings of the $9^{\text {th }}$ International Conference on Social Representations. Jakarta, Indonesia: Graduate Program of European Studies: 87-101

Abric JC (1996) Specific processes of social representations. Papers on Social Representations 5(1): 77-80.

Bauer M, Gaskell G (1999) Towards a paradigm for research on social representations. Journal for the Theory of Social Behavior 29(2): 163-186.

Berkes F, Jolly D (2001) Adapting to climate change: Social-Ecological Resilience in Canadian Western Arctic Community. Conservation Ecology 5(2). Available from: http://bit.ly/1TOoLLx.

Berrang-Ford L, Ford J, Patterson J (2011) Are we adapting to climate change? Global Environmental Change 21 (2011): 25-33.

Betsill MM (2001) Mitigating climate change in US cities: Opportunities and obstacles. Local Environment 6(4): 393-406. 
Claussen E (2001) Foreword. In E Claussen (Ed) Climate change: Science, strategies, and solutions. Arlington, VA: Pew Center on Global Climate Change.

Cotton P (2003) Avian migration phenology and climate change. National Academy of National Sciences of the United States of America 100(2): 12219-12222.

Gomes AMT, Oliveira DC, Sa CP (2008) Social representations of the Brazilian national health care system in the city of Rio de Janeiro, Brazil, according to the structural approach. Rev Latino-am Enfermagem 16(1): 122-129.

Haywood J, Schulz M (2007) Causes of the reduction in uncertainty in the anthropogenic radiative forcing of climate between IPCC (2001) and IPCC (2007). Geophysical Research Letters, 34, L20701, 5 PP., 2007. doi:10.1029/2007GL030749

Hughes 1 (2003) Climate change and Australia: Trends, projections, and impacts. Austral Ecology 28: 423-443.

Hunter P (2003) Climate change and waterborne and vector-borne disease.Journal of Applied Microbiology 94: 37-46. DOI:10.1046/j.1365-2672.94.s1.5.x.

IPCC (2007) Climate change 2007: Synthesis report. Cambridge, UK: Cambridge University Press

Jodelet D (2006) Représentation Sociales [Social Représentations Theory]. Le Dictionnaire des Sciences Humaines. Paris: PUF. Retrieved April 23, 2008 from: http://bit.ly/1BCCOxA.

Jose AM, Cruz N (1999) Climate Change impacts and resources in the Philippines: Water resources. Climate Research, 12: 77-84.

Kelkar U, Bhadwal S (2007) South Asian regional study on climate change impacts and adaptation: Implications for human development. Human Development Report 2007.

Levin-Rozalis M (2001) Social representations as emerging from social structure: the case of the Ethiopian immigrants to Israel. Papers on Social Representations 9: 1.1-1.22.

Moscovici S (1988) Notes towards a description of social representations. European Journal of Social Psychology 18: 211-250.

Moscovici S (2001) Why a theory of social representations. In K Deaux, G Philogene (Eds) Representations of the Social. Cambridge, MA: Blackwell Publishing Inc: 8-35.

O'Brien KL, Leichenko RM (2000) Double exposure: Assessing the impacts of climate change within the context of economic globalization. Global Environment Change 10: 221-232.

Patz JM, Campbell-Lendrum D, Holloway T, Foley J (2005) Impact of regional climate change on human health. Nature Publishing Group, 438: 310-317. doi:10.1038.

Roland-Levy C, Boumelki FP, Guillet E (2010) Representation of the financial crisis: Effect on social representations. The Journal of Socio-Economics 39: 142-149.

Tompskin EL, Adger WN (2004) Does adaptive management of natural resources enhance resilience to climate change? Ecology and Society 9(2).

Wachelke JF (2008) Brazilian fans' social representations on soccer. International Journal of Sports Science 4(4): 1-19.

Wagner W, Duveen G, Farr R, Jovchelovitch S, Lorenzi-Cioldi F, Marková I, Rose D (1999) Theory and method of social representations. Asian Journal of Social Psychology 2: 95-125. 